\title{
SERUM ENDOCAN LEVELS IN RELATION TO TRADITIONAL AND NON-TRADITIONAL ANTHROPOMETRIC INDICES IN ADULT POPULATION
}

\author{
SERUMSKE VREDNOSTI ENDOKANA U ODNOSU NA TRADICIONALNE I \\ NETRADICIONALNE ANTROPOMETRIJSKE PARAMETRE U POPULACIJI ODRASLIH
}

\author{
Aleksandra Klisic ${ }^{1}$, Nebojsa Kavaric ${ }^{1}$, Vesna Spasojevic-Kalimanovska², \\ Jelena Kotur-Stevuljevic ${ }^{2}$, Ana Ninic ${ }^{2}$ \\ ${ }^{1}$ Primary Health Care Center, University of Montenegro-Faculty of Medicine, Podgorica, Montenegro \\ ${ }^{2}$ Department for Medical Biochemistry, University of Belgrade - Faculty of Pharmacy, Belgrade, Serbia
}

\section{Summary}

Background: Association between endocan and nontraditional anthropometric indices, as distinct cardiovascular disease risk factors, has not been examined in previous studies. Endocan is a novel inflammation biomarker with its higher levels involved in cardiometabolic diseases development. Taking into consideration that obesity is an independent risk factor for many cardiometabolic diseases, we aimed to explore the relationship between endocan levels and novel anthropometric indices [i.e., body adiposity index (BAI), cardiometabolic index (CMI), a body shape index, body roundness index, conicity index, lipid accumulation product index and visceral adiposity index] and traditional ones [i.e., waist circumference, hip circumference, body mass index, waist-toheight ratio and waist-to-hip ratio] in adult population.

Methods: A total of 177 participants were included. Anthropometric indices and biochemical parametres were measured.

Results: Univariate regression analysis demonstrated positive correlations of endocan and almost all anthropometric data. To explore independent associations of endocan and anthropometric parameters, the Model which fulfilled criteria for ordinal regression testing was created. Adjusted

\section{Kratak sadržaj}

Uvod: Povezanost endokana sa netradicionalnim antropometrijskim parametrima, kao različitim faktorima rizika za kardiovaskularne bolesti, nije ispitivana u prethodnim studijama. Endokan je novi biomarker inflamacije, čije su veće vrednosti zabeležene kod kardiometaboličkih poremećaja. Znajući da je gojaznost nezavisan faktor rizika za mnoga kardiometabolička oboljenja, cilj je bio da se ispita povezanost endokana i novih antropometrijskih pokazatelja [tj. indeks telesne gojaznosti (BAI), kardiometabolički indeks (CMI), indeks oblika tela, indeks zaokruženosti tela, indeks koniciteta, indeks produkata lipidne akumulacije i indeks visceralne gojaznosti] i onih tradicionalnih [tj. obim struka, obim kukova, indeks telesne mase, odnos obim struka/ telesna visina, odnos obim struka/obim kukova] u populaciji odraslih.

Metode: Ukupno 177 ispitanika je učestvovalo u istraživanju. Mereni su antropometrijski i biohemijski parametri. Rezultati: Univarijantna regresiona analiza je pokazala pozitivnu korelaciju endokana i skoro svih ispitivanih antropometrijskih parametara. U cilju daljeg ispitivanja postojanja nezavisnih korelacija endokana i antropometrijskih parametara, kreiran je Model koji je zadovoljio kriterijume za ordinalnu regresiju. Prilagođeni Odds-ovi za BAI u Modelu

Address for correspondence:

Aleksandra Klisic, MD PhD

Center for Laboratory Diagnostics, Primary Health Care

Center, University of Montenegro-Faculty of Medicine,

Podgorica, Montenegro

Trg Nikole Kovacevica 6, 81000 Podgorica, Montenegro

Phone and Fax: +382 20481999

e-mail: aleksandranklisic@gmail.com 
odds for $\mathrm{BAl}$ given in the Model $(\mathrm{OR}=1.120,95 \% \mathrm{Cl}$ $1.036-1.212, P=0.004)$, demonstrated that a rise in BAl by 1 unit increased the probability of higher endocan concentration by $12 \%$. As well, a rise in $\mathrm{CMI}$ for 1 unit, increased the probability for higher endocan levels for 2.6 times $(\mathrm{OR}=2.599,95 \% \mathrm{Cl} 1.006-6.712, P=0.049)$. A total of $20.1 \%$ of variation in endocan levels could be explained by this Model.

Conclusions: Non-traditional obesity indices, BAI and CMI independently correlated with higher serum endocan levels in adult population.

Keywords: cardiometabolic risk, endocan, inflammation, obesity

\section{Introduction}

Endocan is an intriguing proteoglycan tightly connected with endothelial dysfunction and concomitant inflammation (1). Recent studies have shown higher level of this inflammation marker in many cardiometabolic diseases, such as type 2 diabetes (2), chronic kidney disease (3), fatty liver disease (4), hypertension (5).

On the other hand, obesity is an established risk factor for such cardiometabolic diseases $(6,7)$. The increased inflammation markers in adipocites and disbalance in free radicals production and antioxidant defence, increased flux of free fatty acids and dysfunction of hepatocytes, are some of the potential mechanisms linking obesity and cardiovascular disease (CVD). In addition to this, impaired insulin signaling pathways, diminished nitric oxide production with associated vasoconstriction and endothelial dysfunction are also contributing mechanisms to such pathophysiology (7-10).

However, there are discordant results about relationship between serum endocan level and obesity. Namely, some studies reported lower endocan levels in the obese state (11), as well as an inverse association between circulating level of endocan and the most commonly used obesity indices, such as body mass index (BMI) (12-14) and waist circumference (WC) (15) in different population groups. Contrary to this, the others showed the positive association between circulating endocan level and mentioned obesity indices, BMI (16-18) and WC (18).

Knowing that several recent studies revealed discrepant results considering this relationship with traditional anthropometric parameters, we aimed to obtain deeper understanding into the potential link between obesity and serum endocan level. Importantly, no studies have examined the association between endocan and non-traditional anthropometric indices so far. In line with this, numerous researches suggest that novel non-traditional anthropometric parameters can be better indicators of higher cardiometabolic risk, than traditional commonly used ones (19-25).
$(\mathrm{OR}=1,120,95 \% \mathrm{Cl}$ 1,036-1,212, $P=0,004)$, su pokazali da je porast BAl za 1 jedinicu povećao verovatnoću za porast koncentracije endokana za 12\%. Takođe, porast $\mathrm{CMI}$ za 1 jedinicu, povećao je verovatnoću za veće vrednosti endokana za 2,6 puta $(\mathrm{OR}=2,599,95 \% \mathrm{Cl} 1,006$ $6,712, P=0,049$ ). Ukupno $20,1 \%$ varijabiliteta u vrednostima koncentracije endokana može biti objašnjeno ovim Modelom

Zaključak: Netradicionalni pokazatelji gojaznosti, BAI i CMI su nezavisno povezani sa većim vrednostima endokana u populaciji odraslih.

Ključne reči: kardiometabolički rizik, endokan, inflamacija, gojaznost

Therefore, this study aimed to explore the relationship between endocan levels and new anthropometric indices [i.e., body adiposity index (BAI), cardiometabolic index (CMI), a body shape index $(\mathrm{ABSI})$, body roundness index (BRI), conicity index $(\mathrm{Cl})$, lipid accumulation product index (LAP) and visceral adiposity index ( $\mathrm{VAI})]$ and traditional ones [i.e., BMI, WC, hip circumference $(\mathrm{HC})$, waist-toheight ratio $(\mathrm{WH}+\mathrm{R})$ and waist-to-hip ratio $(\mathrm{WHR})]$ in adult population.

\section{Materials and Methods}

\section{Subjects}

A total of 177 individuals (70.6\% women) participated in this cross-sectional study. The research was conducted between May and July 2017 in the Primary Health Care Center in Podgorica, Montenegro. The Institutional Ethics Committee approved the research protocol. Participants were enrolled in a consecutive manner and each of them signed an informed consent of willingness to be included in the study.

The eligibility to enter the study were: subjects older than 18 years, free of diabetes, CVD, chronic kidney disease, carcinomas, autoimmune and inflammatory diseases, as well as without endocrine disorders (e.g., hypo- and hyperthyroidism, Cushing disease). Another criterion for the persons to be included in this study was that they were not under any weight loss programme and that their body weight did not vary in the previous 3 months.

Exclusion criteria were: alcohol consumption, acute inflammation [high sensitivity $\mathrm{C}$-reactive protein (hsCRP) $>10 \mathrm{mg} / \mathrm{L}$, pregnancy, lactation, as well as biochemical confirmation of diabetes (i.e., fasting glucose $\geq 7.0 \mathrm{mmol} / \mathrm{L}$, or glucose level $\geq 11.1$ $\mathrm{mmol} / \mathrm{L}, 2$ hours after an oral glucose tolerance test, or glycated hemoglobin level $\geq 6.5 \%$ on two different determinations), anti-inflammatory and antidiabetic drugs use.

Traditional anthropometric parameters were taken (weight, height, WC, HC), and BMI, WHtR and WHR were calculated, as described elsewhere (19). 
The BAI was calculated by the following equation (20):

$$
\left[\mathrm{HC}(\mathrm{cm}) \div \text { height }(\mathrm{m})^{1.5}\right]-18 \text {, }
$$

The BRI was calculated, as follows (21): height) ${ }^{2}$

$\mathrm{BRI}=364.2-365.5 \times \sqrt{ } 1-(\mathrm{WC} / 2 \pi)^{2} /(0.5 \times$

The $\mathrm{Cl}$ was calculated using the equation (22): $(\mathrm{cm})$ ]

$\mathrm{Cl}=\mathrm{WC}(\mathrm{cm}) /[0.109 \times$ weight $(\mathrm{kg}) /$ height

$A B S I$ was calculated, as follows (23): $\mathrm{kg}^{-2 / 3}$

$\mathrm{WC} /\left(\mathrm{BMI}^{2 / 3} \times\right.$ height $\left.^{1 / 2}\right)$, expressed in $\mathrm{m}^{11 / 6}$

The CMI was calculated using the formula (24):

$\mathrm{CMI}=\mathrm{TG} / \mathrm{HDL}-\mathrm{c} \times \mathrm{WH} \mathrm{tR}$,

where triglycerides (TG) and high density lipoprotein cholesterol (HDL-c) are expressed in $\mathrm{mmol} / \mathrm{L}$.

The VAl was calculated, as follows (25):

$\{[\mathrm{WC} / 36.58+(1.89 \times \mathrm{BMI})] \times(\mathrm{TG} / 0.81) \times$ (1.52/HDL-c) $\}$ for women, and $\{[\mathrm{WC} / 39.68+(1.88$ $\times \mathrm{BMI})] \times(\mathrm{TG} / 1.03) \times(1.31 / \mathrm{HDL}-\mathrm{c})\}$ for men,

where $W C$ is expressed in $\mathrm{cm}, \mathrm{BMl}$ in $\mathrm{kg} / \mathrm{m}^{2}$, TG and $\mathrm{HDL}-\mathrm{C}$ in $\mathrm{mmol} / \mathrm{L}$.

The LAP was calculated using the formula (26):

LAP $=[(W C-58) \times T G]$ for females, and [(WC65) $\times$ TG] for males, $\mathrm{mmol} / \mathrm{L}$.

where WC is expressed in $\mathrm{cm}$, and $T G$ in

\section{Methods}

The blood samples were taken in 7.00-9.00 a.m. after participants fasted at least 8 hours. In order to obtain sera, samples were left to clot within 30 minutes and then centrifuged at room temperature for 10 minutes at $3000 \mathrm{xg}$.

Serum endocan levels were determined by using an enzyme-linked immunosorbent commercial assay (ab213776 - Human ESM1 ELISA Kit, Abcam, Cambridge, UK).

Immunoturbidimetric method was used for determination of $\mathrm{HbA} 1 \mathrm{c}$ in samples of a whole blood [Roche Cobas c501 chemistry analyzer (Roche Diagnostics GmbH, Mannheim, Germany)]. Serum glucose and lipid parameters (i.e., TG and HDL-c) were measured spectrophotometrically, on the same autoanalyzer as HbA1c. Serum hsCRP level was obtained by nephelometric assay (Behring Nephelometer Analyzer, Marburg, Germany).

\section{Statistical analysis}

Data distribution was examined by KolmogorovSmirnov test. Normally distributed data were presented as arithmetic mean \pm standard deviation and compared by one-way analysis of variance with Tuckey post hoc test. Data with distribution that achieved normality after logarithmic transformation were presented as geometric mean and 95\% Confidence Interval and compared by one-way analysis of variance with Tuckey post hoc test. Skewed distributed data were presented as median (interquartile range) and compared by Kruskal-Wallis and Mann-Whitney tests, depended on the number of tested groups. Categorical variables were compared by Chi-square test for contingency and presented as absolute frequencies.

Associations of endocan and anthropometric data were tested by non-parametric Spearman's correlation analysis and data were presented as Spearman's coefficient correlation ( $\rho)$. Ordinal regression analysis was used to estimate potential independent prediction of anthropometric markers (independent variables) on endocan levels (dependent variable given as tertiles). All the assumptions for univariate and multivariate ordinal regression analysis were taken into account when performing such statistical analysis. Those were as follows: model fitting information had significant Chi-square value $(P<0.05)$, goodness-of-fit test had $P>0.05$ and test of parallel lines had $P>0.05$. Also, anthropometric markers were tested for multicollinearity and those which were in mutual collinearity (VIF $>4$ ) were excluded from the models. Inclusion criteria for markers entering the models were those that had significant correlation with endocan levels when tested by Spearman's correlation analysis for continuous variables and statistical significant difference between endocan tertile groups tested by Chi-square test for categorical data. Data from these analyses were presented as the estimated odds ratio (95\% Confidence Intervals). The explained variation in endocan levels was given by Nagelkerke $R^{2}$ value. Statistical analyses were performed using SPSS ${ }^{\circledR}$ Statistic version 22 (Chicago, USA). Two-tailed $P$ values less than 0.05 were set as statistically significant.

\section{Results}

Anthropometric characteristics of study population according to endocan tertiles levels were shown in Table I. Tested groups had similar gender, hypolipidemic and antihypertensive users distribution. Also, examinees were of similar age in all three groups. The lowest number of smokers was in the third endocan tertile group. The patients in the highest endocan tertile group had higher weight, BMI, WC, HC, WHtR, $B A I, B R I$ and LAP than those from the first and the second tertile group. 
Table I Anthropometric data according to endocan tertiles.

\begin{tabular}{|c|c|c|c|c|}
\hline & $\begin{array}{l}\text { The first endocan } \\
\text { tertile group }\end{array}$ & $\begin{array}{l}\text { The second endocan } \\
\text { tertile group }\end{array}$ & $\begin{array}{l}\text { The third endocan } \\
\text { tertile group }\end{array}$ & $P$ \\
\hline $\mathrm{N}$ (male/female) & $59(21 / 38)$ & $59(15 / 44)$ & $59(16 / 43)$ & 0.430 \\
\hline Age, years & $58.9 \pm 10.4$ & $60.9 \pm 9.2$ & $61.8 \pm 9.5$ & 0.270 \\
\hline Smokers, (yes/no) & $18 / 41$ & $15 / 44$ & $5 / 54$ & 0.009 \\
\hline Hypolipidemics, (yes/no) & $15 / 44$ & $19 / 40$ & $12 / 47$ & 0.337 \\
\hline Antihypertensives, (yes/no) & $25 / 34$ & $33 / 26$ & $35 / 24$ & 0.149 \\
\hline Weight, $\mathrm{kg}^{\dagger}$ & 77 (70-88) & $76(66-88)$ & $81(76-94)^{a \ddagger, b \#}$ & 0.007 \\
\hline Height, $\mathrm{cm}^{\dagger}$ & $170(164-175)$ & $168(162-172)$ & $165(162-174)$ & 0.282 \\
\hline $\mathrm{BMI}, \mathrm{kg} / \mathrm{m}^{2 \dagger}$ & $26.8(25.2-28.6)$ & $26.8(24.0-29.0)$ & $30.5(27.9-32.6)^{a^{*}, b^{*}}$ & $<0.001$ \\
\hline $\mathrm{WC}, \mathrm{cm}$ & $95 \pm 9$ & $94 \pm 11$ & $100 \pm 9^{a} \neq, b \#$ & 0.001 \\
\hline $\mathrm{HC}, \mathrm{cm}$ & $105 \pm 7$ & $105 \pm 9$ & $111 \pm 7^{a^{*}, b^{*}}$ & $<0.001$ \\
\hline $\mathrm{WH}+\mathrm{R}^{\dagger}$ & $0.55(0.53-0.58)$ & $0.55(0.51-0.60)$ & $0.59(0.56-0.63)^{a^{*}, b^{*}}$ & $<0.001$ \\
\hline WHR & $0.90 \pm 0.07$ & $0.89 \pm 0.07$ & $0.90 \pm 0.06$ & 0.384 \\
\hline BAl & $29.51 \pm 4.63$ & $30.53 \pm 4.68$ & $33.66 \pm 4.59^{a^{*}, b \#}$ & $<0.001$ \\
\hline $\mathrm{Cl}$ & $1.28 \pm 0.07$ & $1.27 \pm 0.08$ & $1.29 \pm 0.06$ & 0.426 \\
\hline $\mathrm{BRI}^{\dagger \dagger}$ & $4.42(4.18-4.68)$ & $4.37(4.06-4.71)$ & $5.31(5.04-5.60)^{a^{*}, b^{*}}$ & $<0.001$ \\
\hline $\mathrm{ABSI}$ & $0.08 \pm 0.01$ & $0.08 \pm 0.01$ & $0.08 \pm 0.01$ & 0.827 \\
\hline $\mathrm{CMI}^{\dagger}$ & $0.46(0.35-0.99)$ & $0.75(0.37-1.11)$ & $0.96(0.50-1.26)$ & 0.058 \\
\hline $\mathrm{VAl}^{\dagger \dagger}$ & $15.1(12.1-18.8)$ & $1.73(1.46-2.06)$ & $1.91(1.60-2.27)$ & 0.128 \\
\hline $\operatorname{LAP}^{\dagger}$ & $45.98(31.51-73.01)$ & $59.40(35.25-84.09)$ & $78.00^{a^{*}, b^{*}}(49.66-99.90)$ & 0.006 \\
\hline Endocan, ng/L & $1.51(1.21-1.88)$ & $30.3(24.5-34.9)^{a^{*}}$ & $84.9(59.3-105.4)^{a^{*}, b^{*}}$ & $<0.001$ \\
\hline
\end{tabular}

Data are presented as arithmetic mean \pm standard deviation and compared by one-way ANOVA with Tuckey post hoc test.

$†$ †ata are presented as median (interquartile range) and compared by Kruskal-Wallis and Mann-Whitney tests.

$\dagger \dagger$ Data are presented as geometric mean (95\% Confidence Interval) and compared by one-way ANOVA with Tuckey post hoc test after logarithmic transformation.

a-significantly different from the first endocan tertile group

b-significantly different from the second endocan tertile group

${ }^{*} P<0.001 ; \# P<0.01, \ddagger P<0.05$

BMI-Body mass index; WC-Waist circumference; HC-Hip circumference; WHtR-Waist-to-Height ratio; WHR-Waist-to-Hip ratio; BAIBody adiposity index; Cl-Conicity index; BRI-Body roundness index; ABSI-A body shape index; CMI-Cardiometabolic index; VAIVisceral adiposity index; LAP-Lipid accumulation product index

Non-parametric Spearman's correlation analysis revealed that endocan correlated positively with age, weight, BMI, WC, HC, WHtR, BAI, BRI, CMI, VAl and LAP (Table II). However, the mentioned correlations are relatively weak.

Anthropometric data that showed significant Spearman's correlation coefficient were further tested by regression analysis. Results of univariate and multivariate ordinal regression analysis of endocan tertile levels as dependent variable and anthropometric data as independent variables were given in Table III.

Univariate regression analysis demonstrated significant positive correlations of endocan and almost all anthropometric data. Positive association of endo- can and VAl had borderline statistical significance. To explore the independent associations of endocan and anthropometric data, the Model which fulfilled criteria for ordinal regression testing was created. Adjusted odds for $\mathrm{BAl}$ given in the Model $(\mathrm{OR}=1.120,95 \% \mathrm{Cl}$ 1.036-1.212, $P=0.004)$, demonstrated that a rise in BAl by 1 unit increased the probability of higher endocan concentration by $12 \%$. As well, adjusted odds for $\mathrm{CMI}$ reached statistical significance, demonstrating that a rise in $\mathrm{CMI}$ for 1 unit, raised probability for higher endocan levels for 2.6 times $(O R=2.599$, $95 \% \mathrm{Cl} 1.006-6.712, P=0.049)$. Nagelkerke $\mathrm{R}^{2}$ for the Model was 0.201 which indicated that $20.1 \%$ of variation in endocan levels could be explained by the Model. 
Table II Spearman's correlation analysis of endocan and anthropometric characteristics.

\begin{tabular}{|c|c|c|}
\hline & Rho $(\rho)$ & $P$ \\
\hline Age, years & 0.180 & 0.017 \\
\hline Weight, $\mathrm{kg}$ & 0.154 & 0.040 \\
\hline Height, cm & -0.110 & 0.145 \\
\hline $\mathrm{BMI}, \mathrm{kg} / \mathrm{m}^{2}$ & 0.284 & $<0.001$ \\
\hline WC, cm & 0.215 & 0.004 \\
\hline $\mathrm{HC}, \mathrm{cm}$ & 0.342 & $<0.001$ \\
\hline WHtR & 0.303 & $<0.001$ \\
\hline WHR & -0.030 & 0.695 \\
\hline $\mathrm{BAl}$ & 0.333 & $<0.001$ \\
\hline $\mathrm{Cl}$ & 0.078 & 0.304 \\
\hline $\mathrm{BRI}$ & 0.299 & $<0.001$ \\
\hline ABSI & -0.033 & 0.664 \\
\hline CMI & 0.175 & 0.019 \\
\hline VAl & 0.149 & 0.042 \\
\hline LAP & 0.227 & 0.002 \\
\hline
\end{tabular}

Data are presented as correlation coefficient Rho $(\rho)$

BMI-Body mass index; WC-Waist circumference; HC-Hip circumference; WHtR-Waist-to-Height ratio; WHR-Waist-to-Hip ratio; $\mathrm{BAI}-\mathrm{Body}$ adiposity index; $\mathrm{Cl}$-Conicity index; $\mathrm{BRI}-\mathrm{Body}$ roundness index; $A B S I-A$ body shape index; $C M I-$ Cardiometabolic index; VAI-Visceral adiposity index; LAP-Lipid accumulation product index

Table III Estimated odds ratios after ordinal regression analysis for endocan tertile levels.

\begin{tabular}{|c|c|c|c|}
\hline & \multicolumn{2}{|l|}{ Unadjusted } & \\
\hline & OR $(95 \% \mathrm{Cl})$ & $P$ & $\mathrm{R}^{2}$ \\
\hline Age, years & 1.024 (0.995-1.053) & 0.101 & 0.017 \\
\hline Weight, kg & 1.019 (1.001-1.039) & 0.043 & 0.027 \\
\hline $\mathrm{BMI}, \mathrm{kg} / \mathrm{m}^{2}$ & $1.141(1.062-1.225)$ & $<0.001$ & 0.090 \\
\hline WC, $\mathrm{cm}$ & 1.038 (1.010-1.066) & 0.008 & 0.048 \\
\hline $\mathrm{HC}, \mathrm{cm}$ & $1.082(1.043-1.124)$ & $<0.001$ & 0.118 \\
\hline $\mathrm{BAl}$ & $1.151(1.082-1.225)$ & $<0.001$ & 0.133 \\
\hline BRI & 1.559 (1.230-1.978) & $<0.001$ & 0.090 \\
\hline $\mathrm{CMI}$ & 1.835 (1.106-3.043) & 0.019 & 0.040 \\
\hline VAl & 1.215 (1.000-1.475) & 0.050 & 0.026 \\
\hline \multirow[t]{3}{*}{ LAP } & $1.012(1.003-1.020)$ & 0.005 & 0.050 \\
\hline & \multicolumn{2}{|c|}{ Adjusted - Model } & \\
\hline & OR $(95 \% \mathrm{Cl})$ & $P$ & $\mathrm{R}^{2}$ \\
\hline BAl & $1.120(1.036-1.212)$ & 0.004 & \multirow{4}{*}{0.201} \\
\hline BRI & $1.183(0.745-1.876)$ & 0.477 & \\
\hline $\mathrm{CMI}$ & $2.599(1.006-6.712)$ & 0.049 & \\
\hline LAP & $0.990(0.973-1.008)$ & 0.269 & \\
\hline
\end{tabular}

Model included age, BMI, BAI, BRI, CMI, LAP (all continuous variables) and smoking status (categorical variable).

$\mathrm{BMI}$ - Body mass index; WC - Waist circumference; HC - Hip circumference; BAI - Body adiposity index; BRI - Body roundness index; $\mathrm{CMI}$ - Cardiometabolic index; VAI - Visceral adiposity index; LAP - Lipid accumulation product index

\section{Discussion}

As far as we are aware, this is the first study that evaluated potential relationship between endocan and non-traditional anthropometric indices.

The results of the current research show that not only that serum endocan levels positively correlated with the majority of examined anthropometric parameters in univariate regression analysis, but novel obesity indexes, such as BAI and CMI correlated with this biomarker independently in adult population.

Similarly, the utility of $\mathrm{BAI}$ and $\mathrm{CMI}$ for estimating the cardiometabolic risk factors, such as the risk of hypertension and hyperuricemia $(19,27)$ was also shown in previous studies.

Our findings are opposite to previous reports of the inverse association between endocan level and traditional obesity indexes, BMI and/or WC (12-15). The possible discrepancies in such results may be explained with the age and sex differences, as well as different ethnic groups that previous studies included. Also, the extent of obesity and phenotypes of adiposity vary significantly among individuals which may also explain this controversies.

The BMl is the most common used parameter for the general obesity assessment. However, it has some drawbacks, which can not give information on the body shape and distribution of adipose tissue, neither can distiguish fat depots and muscle mass (19).

The WC, WHR, and WHtR can provide better information on abdominal obesity than BMI. But the latter ones are limitted to fully differentiate visceral from subcutaneous fat (19).

In order to overcome these drawbacks of traditional anthropometric parameters, some novel obesity indices are emerged (27).

The BAl is derived from $\mathrm{HC}$ and height measurements and estimates subcutaneous adipose tissue and the body fat percentage better than BMI (20), and represents better screening tool for coronary risk in adult population than BMI (28). The three other indices that assess body shape, BRI (i.e. derived from height and WC), $\mathrm{Cl}$ and $\mathrm{ABSI}$ (i.e. both calculated from weight, height and WC) are also shown to be convenient predictors of body fat distribution (21-23).

The new indicators of abdominal obesity (i.e. CMI, VAI, and LAP), beside WC include lipid parameters to better differentiate subcutaneous from visceral adipose tissue, and to better discriminate cardiometabolic risk than traditional indices (24-26). Additionally, CMI besides WHtR, include TG/HDL-c ratio (24) which inversely correlates with the plasma level of small dense LDL particles, that are more atherogenic than larger LDL-particles (29). 
In our study, among all examined traditional and novel anthropometric indexes, BAI and CMI correlated independently with endocan in adult population. These findings might enable easier assessment of phenotypes of adiposity that are related to higher endocan level, and consequently higher cardiometabolic risk. These indexes are cost-effective and easy-obtained in everyday clinical practice.

The first study that examined endocan in relation to adipose tissue was conducted by Wellner et al. (30) showing that adipocytes express endocan (previously known as endothelial specific molecule, ESM-1). In line with this Janke and al. (11) reported lower serum endocan levels in overweight/obese postmenopausal women. They also provided subcutaneous abdominal adipose tissue from those women and showed higher expression of endocan in human adipocytes than in preadipocytes. Interestingly, after weight loss programme, serum endocan levels significantly increased, but its expression in adipocytes did not change, suggesting that some other sites of endocan secretion may be more important (e.g. lungs, kidneys) (11).

Our study included more participants that Janke's et al. (11) did and examined both genders. This might explain discordant results. Additionally, we excluded each participant with acute inflammation, to diminish confounding efects on serum endocan level. Namely, it was shown that many pro-inflammatory cytokines induce endocan expression in vitro (e.g., interleukin-1, vascular endothelial growth factor, tumor necrosis factor-alpha, transforming growth factor-beta-1, fibroblast growth factor-2) (31), and some mytogens in adipocytes (e.g., retinoic acid and phorbol ester) (30).

Recently, endocan expression was also reported to be increased in the human placenta from obese women with gestational diabetes mellitus (32) and in reaction to pro-inflammatory stimuli, thus implying that endocan may take part in the states caracterized with increased inflammation. Indeed, not only that the expression of this biomarker is increased by different cytokines' stimuli, but endocan per se can trigger endothelial cells to secrete a wide spectrum of other cytokines and enhance leukocytes migration. Moreover, its influence on increased blood vessels permeability is detected, which altogether makes this biomarker reliable for increased cardiometabolic risk recognition (33).
The limitation of this study is its cross-sectional design which can not confirm the causal relationship between endocan and obesity indexes. Furthermore, in the second and the third endocan tertile group there were more females than males than in the first group, and the gender effect might be some source of bias. As well, patients were not asked to discontinue antihypertensive and lipid lowering therapy, which might affect serum endocan levels, as well as some anthropometric indices (CMI, VAI, LAP). At last, we were not able to use precise imaging techniques, for more accurate assessment of visceral compartments. However, contrary to some previous studies, we have shown the positive association of endocan with a wide spectrum of anthropometric indices, both traditional and non-traditional ones. Future studies which will include participants with obesity, without other comorbidities and without any medicament therapy use, might be useful to better evaluate the influence of obesity on serum endocan level.

\section{Conclusion}

Non-traditional obesity indices, BAI and CMI independently correlated with higher serum endocan levels in adult population. Screening for obesity with paying attention on both, total body fat (determined by increased $\mathrm{BAI}$ ) and visceral adipose tissue distribution (defined by higher CMI) might be useful to differentiate patients with higher endocan levels, and consequently higher cardiometabolic risk. New prospective studies are needed to confirm our results and enlighten the causal relationship between endocan and obesity indexes.

Acknowledgement. This work was financially supported in part by a grant from the Ministry of Science, Montenegro and the Ministry of Education, Science and Technological Development, Republic of Serbia (project number 451-03-68/2020-14/200161).

\section{Conflict of interest statement}

All the authors declare that they have no conflict of interest in this work. 


\section{References}

1. Cimen AO, Emet S, Elitok A. Endocan: a biomarker predicting successful reperfusion after coronary artery bypass surgery of acute coronary syndrome patients. Eur Rev Med Pharmacol Sci 2019; 23: 338-42.

2. Klisic A, Kavaric N, Stanisic V, Vujcic S, SpasojevicKalimanovska V, Ninic A, Kotur-Stevuljevic J. Endocan and a novel score for dyslipidemia, oxidative stress and inflammation (DOI score) are independently correlated with glycated hemoglobin (HbA1c) in patients with prediabetes and type 2 diabetes. Arch Med Sci 2020; 16(1): 42-50.

3. Ekiz-Bilir B, Bilir B, Aydın M, Soysal-Atile N. Evaluation of endocan and endoglin levels in chronic kidney disease due to diabetes mellitus. Arch Med Sci 2019; 15(1): 8691.

4. Klisic A, Kavaric N, Abenavoli L, Stanisic V, SpasojevicKalimanovska V, Kotur-Stevuljevic J, Ninic A. Is endocan a novel potential biomarker of liver steatosis and fibrosis? J Med Biochem 2020; 39(3): 363-71.

5. Klisic A, Kavaric N, Vujcic S, Spasojevic-Kalimanovska V, Ninic A, Kotur-Stevuljevic J. Endocan and advanced oxidation protein products in adult population with hypertension. Eur Rev Med Pharmacol Sci 2020; 24(12): 7131-7137. doi: 10.26355/eurrev_202006_21707

6. Maksimovic M, Vlajinac H, Radak Dj, Marinkovic J, Maksimovic J, Jorga J. Association of overweight and obesity with cardiovascular risk factors in patients with atherosclerotic diseases. J Med Biochem 2020; 39(2): 215-23.

7. Tong J, Guo JJ. Key molecular pathways in the progression of non-alcoholic steatohepatitis. Eur Rev Med Pharmacol Sci 2019; 23(19): 8515-22.

8. Ates E, Set T, Karahan SC, Biçer C, Erel Ö. Thiol/disulphide homeostasis, ischemia modified albumin, and ferroxidase as oxidative stress markers in women with obesity with insulin resistance. J Med Biochem 2019; 38(4): 445-51.

9. Naghizadeh M, Saghafi-Asl M, Amiri P, Karamzad N. Lipid profile in relation to inflammatory and insulin resistance markers and anthropometric indices in the apparently healthy abdominally obese. Prog Nutr 2019; 21(1S): 370-7.

10. Moradi M, Alvandi E, Koohdani F. The Effect of obesity and weight loss through calorie restriction on HDL function. Prog Nutr 2019; 21(1-S): 16-24.

11. Janke J, Engeli S, Gorzelniak K, Feldpausch M, Heintze $U$, Böhnke J, et al. Adipose tissue and circulating endothelial cell specific molecule-1 in human obesity. Horm Metab Res 2006; 38(1): 28-33.

12. Delibas IB, Yapca OE, Laloglu E. Does endocan level increase in women with polycystic ovary syndrome? A case - control study. Ginekol Pol 2018; 89(9): 500-5.

13. Yilmaz MI, Siriopol D, Saglam M, Kurt YG, Unal HU, Eyileten $T$, et al. Plasma endocan levels associate with inflammation, vascular abnormalities, cardiovascular events, and survival in chronic kidney disease. Kidney Int 2014; 86(6): 1213-20.
14. Musialowska D, Zbroch E, Koc-Zorawska E, Musialowski P, Malyszko J. Endocan Concentration in Patients With Primary Hypertension. Angiology 2018; 69(6): 483-9.

15. Rodrigues KF, Pietrani NT, Bosco AA, Sousa LP, Ferreira $\mathrm{CN}$, Sandrim VC, et al. Endocan: a new biomarker associated with inflammation in type 2 diabetes mellitus? Diabetes Metab Res Rev 2015; 31(5): 479-80.

16. Elkamshoushi AM, Omar SS, El Abd AM, Hassan SZ, Sultan EA, Abd Elkawy E. Subclinical atherosclerosis in psoriatic disease: relation to endocan, $\mathrm{TNF}-\alpha$, age of onset, and body fat. Int J Dermatol 2019; 58(4): 45664.

17. Gungor A, Palabiyik SS, Bayraktutan Z, Dursun H, Gokkaya N, Bilen A, et al. Levels of endothelial cell-specific molecule-1 (ESM-1) in overt hypothyroidisim. Endocr Res 2016; 41(4): 275-80.

18. Bicer M, Guler A, Unal Kocabas G, Imamoglu C, Baloglu A, Bilgir $O$, et al. Endocan is a predictor of increased cardiovascular risk in women with polycystic ovary syndrome. Endocr Res 2017; 42(2): 145-53.

19. Wang H, Chen Y, Sun G, Jia P, Qian H, Sun Y. Validity of cardiometabolic index, lipid accumulation product, and body adiposity index in predicting the risk of hypertension in Chinese population. Postgrad Med 2018; 130(3): 325-33.

20. Bergman RN, Stefanovski D, Buchanan TA, Sumner AE, Reynolds JC, Sebring NG, et al. A better index of body adiposity. Obesity (Silver Spring) 2011; 19: 1083-9.

21. Thomas DM, Bredlau C, Bosy-Westphal A, Mueller M, Shen W, Gallagher D, et al. Relationships between body roundness with body fat and visceral adipose tissue emerging from a new geometrical model. Obesity (Silver Spring) 2013; 21: 2264-71.

22. Valdez R. A simple model-based index of abdominal adiposity. J Clin Epidemiol 1991; 44: 955-6.

23. Krakauer NY, Krakauer JC. A new body shape index predicts mortality hazard independently of body mass index. PLoS ONE 2012; 7: e39504.

24. Wakabayashi I, Daimon T. The »cardiometabolic index" as a new marker determined by adiposity and blood lipids for discrimination of diabetes mellitus. Clin Chim Acta 2015; 438: 274-8.

25. Amato MC, Giordano C, Galia M, Criscimanna A, Vitabile S, Midiri M, et al. Visceral Adiposity Index: a reliable indicator of visceral fat function associated with cardiometabolic risk. Diabetes Care 2010; 33: 920-2.

26. Biyik Z, Guney I. Lipid accumulation product and visceral adiposity Index: two new indices to predict metabolic syndrome in chronic kidney disease. Eur Rev Med Pharmacol Sci 2019; 23(5): 2167-73.

27. Liu XZ, Li HH, Huang S, Zhao DB. Association between hyperuricemia and nontraditional adiposity indices. Clin Rheumatol 2019; 38(4): 1055-62.

28. Almeida RT, Pereira ADC, Fonseca MJMD, Matos SMA, Aquino EML. Association between body adiposity index and coronary risk in the Brazilian Longitudinal Study of 
Adult Health (ELSA-Brasil). Clin Nutr 2019; pii: S02615614(19)30252-3. doi: 10.1016/j.clnu.2019.06.001.

29. da Luz PL, Favarato D, Faria-Neto JR Jr, Lemos P, Chagas AC. High ratio of triglycerides to HDL-cholesterol predicts extensive coronary disease. Clinics (Sao Paulo) 2008; 63(4): 427-32.

30. Wellner M, Herse F, Janke J, Gorzelniak K, Engeli S, Bechart D, et al. Endothelial cell specific molecule-1--a newly identified protein in adipocytes. Horm Metab Res 2003; 35(4): 217-21.
31. Delehedde $M$, Devenyns $L$, Maurage CA, Vivès RR Endocan in cancers: a lesson from a circulating dermatan sulfate proteoglycan. Int J Cell Biol 2013; 2013: 705027.

32. Murthi P, Sarkis R, Lim R, Nguyen-Ngo C, Pratt A, Liong $S$, et al. Endocan expression is increased in the placenta from obese women with gestational diabetes mellitus. Placenta 2016; 48: 38-48.

33. Lee W, Ku SK, Kim SW, Bae JS. Endocan elicits severe vascular inflammatory responses in vitro and in vivo. J Cell Physiol 2014; 229: 620-30.

Received: March 3, 2020

Accepted: May 15, 2020 